\title{
The Janus Face of Infertility in the Global North and South: Reviewing Feminist Contributions to the Debate
}

Sara MacBride-Stewart and Rachel Simon-Kumar

Introduction

This chapter explores feminist contributions to perspectives on infertility in the global north and global south in the period after the emergence of biomedical techniques (assisted reproductive technologies or ARTs) to overcome infertility. ${ }^{1} \mathrm{~A}$ comparative study of feminist discourses on infertility in these diverse global sites realizes several possibilities. At one level, it offers an account of the historical emergence of infertility critiques in the global north and south, especially in the period from the 1970s onwards, corresponding to the development of late twentieth-century feminist consciousness in both regions. ${ }^{2}$ Some feminist approaches have embraced the view that women are empowered by technologies that promote individual rights and choices in overcoming infertility, while others have been critical of the capacity of reproductive technologies to widen local and global divisions, with increasing evidence of an infertility divide. These contradictions in feminist responses to infertility across the globe mirror more fundamental entanglements between feminism and capitalism. Pitched against the contrasting waves of the rise and decline of capitalism in the 'developing' and the 'developed' world, this chapter highlights how an emphasis on a politics of recognition (including in healthcare) that came to dominate later second wave feminism became aligned with neoliberalism. This is a central thesis of Nancy Fraser's (2013) account of second wave feminism in its global context which is useful for our chapter. While a politics of recognition does not represent all strands of feminist activity 
and influence, Fraser (2013) suggests that its dominance over a politics of redistribution and an emphasis on inequalities perpetuates stratifications and inequities between and amongst women in the global north and the global south. From a conceptual point of view, each new development in reproductive technologies has generated a response from feminist scholars and it is possible to see in the feminist responses to these technologies, the interplay of key feminist debates within a global context. To that extent, as Thompson has argued, "infertility in the age of reproductive technologies has been performed as the perfect feminist text"3

The paper draws on, as its theoretical scaffold, recent commentary by Nancy Fraser on the "dangerous liaisons" between feminism and capitalism. ${ }^{4}$ Her work traces the evolution of feminism from the 1970s, and charts a parallel trajectory between the transition from stateled capitalism to free-market neoliberalism in the global north and south, and feminism's congruent obsessions with a politics of recognition in place of a politics of redistribution. Feminism's neglect of economic and social justice in the 1980s, she argues, reified the stronghold of neoliberalism, which ironically deployed the very vocabularies and critiques of the second wave for its own purposes. What emerged was a rhetoric of individual 'choice' aided by the presence of the free-market in a minimally regulated state, opposite to an emancipatory discourse of collectivist action. The appropriation of feminism by capitalism in effect "served to legitimate a structural transformation of capitalist society that runs directly counter to feminist visions of a just society". 5

In this context, in the global north, medical science progressed as a matter of public concern, with infertility becoming a cause célèbre for reproductive medicine. Scientific progress and emancipatory discourses of work and career aligned feminisms' own goals 
with capitalist goals of productivity. Furthermore, a new wave of regulation focused on reproductive rights reaffirmed the alliances between the state and feminisms, as both sought a political and moral stake in reproductive processes. The encounters of women's rights groups in the global south with capitalism produced similar, although not quite the same, contradictions. Capitalism embedded itself in development discourses and turned its reproductive intent towards anti-natalism. Through the 1980s and 1990s, feminists in the global south fought for the recognition of women's rights in the face of government efforts at population control, while seeking redistribution through fair and just reproductive health care provisioning. However, as a 'new' strand of neoliberalism emerged which fostered the growth of unregulated markets in fertility and infertility, reproductive rights were increasingly discussed in terms of personal choice rather than collective empowerment.

Capitalist transitions, and their concomitant implications for feminism, are the germane ground on which the contradictions of infertility discourses have been inscribed, and are central to the argument we make in this paper. Indeed, the history of late twentieth-century capitalism frames the Janus face history of the feminist discourses of infertility. By tracing these historical transitions in the global north and south, we intend to use feminist critiques (including those of feminism itself) to examine how the entanglements between capitalism and feminism cause infertility to be 'read' onto the bodies of infertile women very differently depending on the wider social and economic context, and produce multiple responses that further compromise a feminist vision of just societies. As Fraser has argued, in the context of accelerating globalization, feminisms' attention to gender injustice transferred from the 'maldistribution' of resources to identity politics and the 'recognition of difference'. ${ }^{6}$ As the paper will go on to show, this switch of focus radically undermined attempts to broaden the 
access of different groups to infertility resources, and generated a series of divisions between and within the global north and south.

The paper is divided into four main parts. We first profile infertility across the two regions. The chapter then explores feminist contributions to understanding the role of medical technologies in 'overcoming infertility' and the consequent revolution in understandings of kinship and conception in the global north. Next, the chapter turns to the global south and summarizes feminist contributions to discussions on gender development and fertility rates, reproductive health services, and population control. Section four examines the implications of the diversity of feminist discourses in both regions, focusing on the reproductive stratifications they have engendered in recent history. Our conclusion critically analyses the Janus face of infertility from our perspective of the inequalities generated as feminism moved into the era of advanced global capitalism.

\section{Profiles of Infertility: Medical Discourse}

Definitions of infertility, the meanings of the terms used to describe it, and mechanisms for recording it vary, making it difficult to reliably compare the incidence of fertility problems on a global scale. ${ }^{7}$ However, attempts to standardize definitions and measurements of infertility enable some judgements about the prevalence of infertility across nations and over time. This matches an incipient goal of the World Health Organization to assess "the magnitude and geographical distribution of infertility". ${ }^{8}$ Early attempts by the WHO to standardize infertility described it as involuntary, related to couples, and distinguishable from childlessness (secondary infertility for example relates to subsequent failures to conceive); there was also scope to include pregnancies in which conception did not lead to 
a live birth. ${ }^{9}$ The $\mathrm{WHO}$ definition of infertility emerged onto the international stage just three years before the birth of Louise Brown, the first child conceived through IVF, and was maintained until at least the end of the same decade. Infertility was extensively redefined into the new millennium ${ }^{10}{ }^{11}$, although with the first IVF birth, the construction of infertility became linked to medical technologies, and the condition was no longer perceived as inevitable. ${ }^{12}$ Despite an extensive bibliography of related ideas and terms (described later), the WHO secured a standardised medical definition of infertility that describes it as "a disease of the reproductive system defined by the failure to achieve a clinical pregnancy after 12 months or more of regular unprotected sexual intercourse". ${ }^{13}$

As early as 1975, infertility was declared "a worldwide problem [whose] frequency varies from area to area". ${ }^{14}$ The first epidemiological studies of infertility prevalence used the average number of children for each woman as a predictor of fertility. Using this data, it has been argued that there was a global increase in fertility rates from the 1950 s to the 1960 s. Although the global population continued to grow, between the 1960 s and the 1980 s there was a decline in average fertility in the Third World from six to four children per woman, ${ }^{15}$ and overall fertility levels declined. ${ }^{161718}$ The same period saw a large increase in rates of infertility. Infertility rates stabilized during the 1990s. ${ }^{19}$ However, as the number of women reaching reproductive age increased, there was a corresponding increase in infertility ${ }^{20}$. The global infertility rate was estimated to be about eight to twelve per cent of reproductive aged women around the world unable to become pregnant or to carry that pregnancy to full term. ${ }^{212223}$ In western populations, estimations of the infertility rate rose to about 14 per cent when they included women who delayed conception until they were older ${ }^{24}$, and excluded women who had opted for sterilization.2526 The infertility rate was also higher in developing countries. ${ }^{27}$ The Demographic and Health Surveys (DHS) programme reported 
that between 1995 and 2001 "more than one-fourth of ever married women of reproductive age in developing countries was infertile". ${ }^{28}$ Infertility prevalence differs between regions and is known to be highest in South Asia, Sub-Saharan Africa, North Africa/Middle East, and Central/Eastern Europe and Central Asia. ${ }^{29}$ These figures increase to rates of 30 per cent or more in areas of sub-Saharan Africa. ${ }^{3031323334}$

Although we now have a fairly clear picture of global population trends from the second half of the twentieth century onwards, there were actually no large-scale studies of infertility before the 1970s. ${ }^{35}$ The above figures are known because of the establishment of the World Fertility Survey (WFS) in 1972, with US and United Nations funding ${ }^{36}$ This focused its efforts on nine sub-Saharan nations. ${ }^{37}$ The first large survey specifically on infertility was conducted in six European countries, the USA and Australia, and published its results in $1999 .{ }^{38}$ Another important resource for demographers interested in infertility patterns comes from the Demographic and Health Surveys (DHS) programme. This collated international data on infertility from 47 surveys in developing countries between 1995 and 2001. ${ }^{39}$ However, because infertility was perceived as such a sensitive area, DHS researchers did not pose direct questions about infertility. Instead, the incidence of infertility was determined through analysis of five key questions in a related area.

As this brief discussion of variance in demographic studies suggests, language, meaning and context are important for determining the prevalence, possible causes and potential treatments of infertility ${ }^{40}$. Standardized biomedical definitions of infertility predominate in the global north. Alongside the WHO definition given above, other clinical studies designate infertility as failure to conceive after one year and up to five years of unprotected sex. ${ }^{41}$ Rates of infertility alter if the measure is based on the "ability to become pregnant rather 
than having a live birth". ${ }^{42}$ Infertility problems are defined differently in various local contexts by different subgroups, or where there is an emphasis on subjective and experiential meanings of infertility, rather than the medicalized definitions discussed so far. It has been noted that while a medicalized definition of infertility predominates in developed societies, in developing societies "biomedical interpretations of infertility coexist...with traditional interpretations". ${ }^{43}$ This can make international comparisons of infertility rates and determination of lifetime prevalence uncertain, and also often leads researchers to "underestimate the extent of suffering the women (and men) endure as a result of fertility problems". ${ }^{44}$ For feminists, there are important moral and economic differences between medically-oriented definitions of the state of not being able to have children (infertility) and more experientially-oriented definitions of the state of not having children (in/voluntary childlessness), and therefore these definitions should remain separate. ${ }^{45}$

During the period that this paper refers to, biomedical developments in infertility escalated. Frank van Balen and Marcia Inhorn describe a shift from the low-tech reproductive technologies such as artificial insemination with donated sperm and oocyte induction with hormones used in the 1950s, to successful IVF in the late 1970s. ${ }^{46}$ The first decade of IVF, the 1980s, led to greater efficiency and accessibility of this form of treatment for a wider range of conditions and women. In the following decade, the 1990s, innovations and refinements led to a range of new infertility treatments including intracytoplasmic sperm injection (ICSI), laparoscopy and egg freezing. ${ }^{47}$ The success of early forms of IVF cannot as some commentators argue - be compared to the developments since the early 1990 s. ${ }^{48}$ In the early days of IVF, infertility clinics would continue to manage and treat patients only if there was a realistic chance of success. ${ }^{49}$ At this stage, before there was an emphasis on the importance of biological ties for parenthood, adoption was a key means of addressing 
personal infertility. ${ }^{50}$ As a wider group of people experiencing infertility were treated using these techniques, public perceptions of ART shifted. It was no longer seen as experimental, but as a standard and viable option for fertility. ${ }^{51}$

The expansion of reproductive technologies has continued into the current decade, and reflects the reach of these technologies into new populations (new expertise/experts and new patient groups/treatable conditions). The expansion in reproductive technologies has arguably broken down the distinctions between infertility and fertility, as women who were born infertile had the possibility of becoming fertile in their lifetime. As such, the identity 'infertile' was not a fixed one. Furthermore, informed patient activists engaged infertility medicine to encourage it to participate in (anticipatory) public ethical and social debate around its practices. ${ }^{52}$ The revolution in reproductive technologies must be viewed as the result of biomedical, global and historical processes that are framed by a postmodern and neoliberal context. These developments have determined the possibilities of women's own participation in shaping their reproductive futures, in ways contingent on wider social and economic circumstances, with opportunities to engage with or to confront biomedicine often unevenly distributed.

\section{Reproduction and Infertility Discourses in the Global North}

Feminists in the global north initially used the dual theoretical framework of reproductive rights and medicalization processes to understand infertility as a social, cultural and biomedical enterprise. In the 1970 s and 1980s, mainstream liberal feminists saw advances in science, technology and policy as providing opportunities for women, and 
consequently supported the development of reproductive technologies. ${ }^{53}$ Despite significant differences between the two strands of feminism in other respects, this tied in with radical feminism's insistence on analysing "women's reproductive experiences...as sources of power as well as subordination", and emphasis on the role of reproductive technologies in overcoming women's economic and physical inequalities, freeing women from the constraints of childbirth. ${ }^{54}$ New reproductive technologies were initially conceived as enabling women 'to 'have it all' by way of family and employment or career. The emphasis was on women 'seiz[ing] the means of reproduction', taking control of their bodies and their lives. ${ }^{55}$ Radical feminists and socialist feminists agreeing with this stance argued that capitalism is founded on women's participation as both producers and reproducers. In very explicit ways, radical feminists such as Firestone claimed that reproductive technologies could sever the tie of patriarchy through a reframing the relationship between reproduction and labour giving women, amongst other things, the right to not have children. ${ }^{56}$ This approach differed from the socialist feminist stance of simply re-ordering labour divisions inscribed in capitalism. Although liberal, radical and socialist feminists had very different perspectives on the desirability of capitalism, it can argued that convergent strands in their philosophies contributed to a situation in which the reproductive health movement in the global north ended up focusing on reproductive rights, choice and opportunity.

From a First World perspective, infertility had begun to be transformed by scientific medicine, reflecting a narrative of opportunity and choice. As the feminist emphasis on the "right to choose" garnered momentum through the 1970 s and 1980 s, a reproductive health agenda that normalized fertility galvanized medical approaches to infertility. As the medicalization of in/fertility proceeded, the condition of infertility came to be defined via the 
treatments available for it; for example, couples were infertile without treatment but fertile with it. ${ }^{57}$ Over time, other groups once identified as non-procreative for example same-sex couples, were routinely labelled infertile (in social discourse). ${ }^{58}$ There was also social pressure for infertile couples to seek fertility treatments rather than to accept infertility or choose other options. ${ }^{59}$ This normalization of infertility treatments was reflected in a reduction in numbers of couples adopting children, although infertility may not be the only reason for this reduction. For example, in the UK the number of children available for adoption fell with the introduction of the contraceptive pill, and as the stigma of unmarried motherhood lessened fewer children overall were being adopted. Formal and informal restrictions on adoption that may have contributed to such a reduction are found in many cultures and societies. ${ }^{60}$ Yet, as critics have noted, the promotion and normalization of ARTs occurred with adoption practices increasingly being constructed as a 'last resort'. ${ }^{61}$ Furthermore, ARTs were promoted with little attention to failure rates, including high numbers of ectopic pregnancy, natural abortion and fetal abnormalities, ${ }^{62}$ or to financial costs, trauma, or moral and ethical concerns. ${ }^{63}$

By the early 1990s, feminists in the global north had raised substantial critical debate over the use of medical technologies, and had outlined critiques of the dominance of science, medicine and technology within approaches to reproductive health. In the late 1970 s and throughout the 1980s, feminist perspectives on medicalization had developed which emphasized the role of medical control over women's bodies, the depersonalization of patients and the objectification of their bodies, resulting in an overall disenfranchisement of women in the medical context. ${ }^{64}$ The medicalization critique drew specific attention to the socially constructed nature of medicine, and its tendency to take control over women's reproduction. ${ }^{65}$ However because medicine is often framed as a social or personal good its 
capacity for social control may not seem obvious. Medical procedures that visualized reproductive processes reduced women's bodily interiors to functional parts and promoted the autonomous status of the foetus, were processes that regulated women and their fertility by offering explanations and control over knowledge of the mysterious inner workings of the body; medicine in this way helped to define abnormal and normal bodily functioning. ${ }^{66}$ Feminist critics argued that medical ideology represented women as passive victims rather than as active agents, and therefore positioned women as having no real choice. However, these critiques of medicalization did not necessarily lead to a condemnation of reproductive technology. Feminists who were cautious about the emancipatory nature of infertility treatments and who resisted scientific discourses still believed that under the right conditions, women could choose whether and how they took up reproductive technologies. ${ }^{67}$

Some authors have argued that the feminist focus on medicalization slowed work on the political and social dimensions of infertility. ${ }^{68}$ Feminist critiques of medicalization often paid little attention to the extent to which new reproductive technologies influenced notions of bodily experience and personhood. Critical feminist analyses of the lived experiences of those treated with ARTs did not occur until the 1990s, as feminist work began to recognize the limitations of neo-Foucauldian poststructuralist discursive theorizations of the body. ${ }^{69} \mathrm{~A}$ theoretical shift towards embodiment highlighted the extent to which new medical technologies had constructed the infertile body as a biophysical disruption remediable by means of biomedical treatments. This research drew attention to the potential of infertility treatments to displace technological determinism and blur the so called nature/culture intersection via the ability to supersede the biological limits of the physical body, providing 
new opportunities for formerly conceptually static bodies that had once been rendered infertile by disease and/or by age.

The medicalization thesis was also complicated by both the growth of neoliberalism which appeared to offer widening of access to infertility treatments through rapid biomedical and technological progress, and an emphasis on 'personal choice', in a process known as biomedicalization. ${ }^{70}$ Descriptions of biomedicalization emphasize the entrenchment of neoliberal values and approaches, as well as 'technoscientific changes in the constitution, organization, and practices of contemporary biomedicine', within medicine. ${ }^{71}$

Biomedicalization theory proposes that the dramatic progress in infertility treatments in the global north since the mid-1980s occurred as part of a multi-sided process of scientific and technological progress focused on overcoming infertility via treatment. In this view, the growth of biomedical approaches to infertility was inextricably tied to specific politicaleconomic conditions (privatization, devolution and rationalization of health services) which produced new biomedical social forms, subjectivities and practices. ${ }^{72}$ In this context, infertility became linked to individualized and consumerist models of medicine. ${ }^{73}$ These processes reflected transformations in infertility and in infertile bodies that paralleled the ideological shifts from second to third wave feminisms towards a more fragmented, individual, and arguably less political approach. From the 1990s onwards, feminist perspectives and advocacy campaigns around women's reproduction emerged out of a politics of recognition, which itself became entwined with processes of biomedicalization. In this period, feminist debates on infertility were also informed by criticisms of biomedicine, by individuals and social movements, which expressed concerns about the extension of medical jurisdiction over infertility. 
Sociologists, social theorists and philosophers interested in infertility were therefore keen to understand how individuals became a target for biomedicalization via practices that constitute patients as consumers. ${ }^{74}$ In the late 1970s and 1980s, consumerist discourses had initially emerged as a means of giving patients choices and autonomy. However, these discourses had unintended effects. More recently, Janet Newman and Ellen Kuhlman have argued that at national and government levels, the ideology of consumer choice had "positive unsettling effects on the pattern of health care", ${ }^{75}$ because the consumption of health goods was not initially regarded as compatible with the goals of biomedicine. Subsequent academic analyses of the growth of reproductive medicine that refer to the 1970 s and 1980s identify how ideologies of consumer choice shaped the commodification of sperm, ova and the womb into what has become a global market in infertility. ${ }^{76}$ These early debates and critiques of the commodification of reproductive technologies were especially concerned with surrogacy arrangements.

From the perspective of feminists in the global north, infertility consumers did not achieve the kinds of autonomy or choice they had initially envisioned in the 1980s. In practice, as new reproductive technologies were introduced consumer practices followed principles of individualized desires and choice, rather than emphasizing collective reproductive rights. Some feminists emphasized the lack of real choice for women, and particularly noted that women's use of ARTs risked reducing them to reproductive commodities. ${ }^{77}$ Some critics noted that the right to choose and the ability to access treatments were constrained by structural and socioeconomic limitations, influenced especially by social class, age and ethnicity. However, as Deborah Lupton points out, "The liberal consumerist-orientated view that women should have a right to choose tend[ed] to ignore such structural constraints". ${ }^{78}$ These authors began to show that infertility treatments were more available to some 
groups of women in the global north, although this fact in itself did not appear to alter reproductive policy.

In the 1990s and 2000s, academics drew attention to the ways in which infertility treatments had also begun to shape understandings about who or what constituted a person. Discussions about new reproductive technologies considered how they constructed the foetus as separate from the mother, as an autonomous rather than a dependent subject. ${ }^{79}$ These issues of autonomy and dependency related to concerns previously raised in debates about abortion over women's rights to autonomy. ${ }^{80}$ However, some critics argued that the use of new reproductive technologies, like many neoliberal projects, became another means to fashion the self and one's life through engaging in the practices of consumption. The infertile body was no longer ill or diseased but was instead constituted by the ideologies of overcoming dis-ease, self-enhancement and bodily 'optimization' ${ }^{81}$ This 'optimization of the body' highlights the use of medical technologies to secure the best possible futures for individuals, linked again to the idea that the physical limitations of the body could be superseded. As discourses of infertility in the global north constituted the condition as often voluntary and caused by socio-economic choices relating to employment and career, infertility treatments were recognized as providing opportunities for individuals to overcome such effects, including but not limited to the effects of aging. These discourses constructed infertility as a gendered problem that is preventable, and remedied by reproductive health care and attention. The enterprise of biological parenting generated by the alleviation of infertility arguably did not cause significant problems for feminism in the third wave, because of its own promotion of individualism and achievement. ${ }^{82}$ 
In addition to early feminist concerns about autonomy and science, feminists became interested in the political effects of the impact of new biomedical identities and subjectivities. One of the more optimistic responses to new reproductive technologies was their capacity to expand notions of kinship. Traditionally, arguments around the medicalization of childbirth, supported by groups such as the Natural Childbirth Movement had critiqued many gynaecological and obstetric interventions on the basis that they "serve[d] to disempower women and restrict their social and economic mobility" ${ }^{83}$ As feminists in the 1990s turned their attention to the potential of new reproductive technologies to radically alter social arrangements and to reshape understandings of family and kinship, they were interested in how ARTs generated new, diverse family forms. The ART movement expanded the concept of mother, parent and family, while emphasis on the rights of individuals gave new groups such as gay fathers access to reproductive services. The reimagining of family forms attendant on the possibilities offered by ART is reflected in an explosion of terms such as 'birth mother' 'egg mother' and 'surrogate mother'. ${ }^{84}$ Motherhood came to include genetic, birth, adoptive and surrogate maternities, and egg donors were recognized as 'parents'. This language was commensurate with the lack of a distinction between social and biological parenting when people talked about their families. Academics also noted the decoupling of the relationship between parents and their offspring, reflected in a discursive shift from 'reproduction' to 'procreation'. In its place, the emerging discourse of procreation had 'different connotations', namely that of intervention and propagation and the loss of women's autonomy over their reproduction. ${ }^{85}$ This is partly because new reproductive technologies opened up even more radical opportunities for conception and sexual relations, with ovum capable of being fertilized outside the womb. For example, in 1986 Ann Oakley raised the science fiction-type scenario of "male (abdominal) pregnancy [or]...entirely-laboratory made human pregnancy [...] beginning 
with the glass dish and ending with the neonatal intensive care unit". ${ }^{86}$ Consequently, infertility treatments were recognized by academics as important for society because they involved a range of social actors and created new narratives and possibilities for (infertile) bodies and parenting.

The question of ethical and moral issues in reproductive rights focused feminist thinking on political and government regulation. Arguably, feminisms in the second wave held the belief that the welfare state would supplement any inequalities in health care services, as part of its mission to uphold the rights of all individuals to adequate health provision. Accessibility to IVF had been enabled by permissive legislation in a number of countries in the global north, along with "generous reimbursement policies, as well as a general public confidence in IVF" ${ }^{87}$ Then, as neoliberalist policies began to unpick the welfare state, feminism's attempt to include ethnicity and sexuality in the redistribution of reproductive health was undermined. Subsequently, feminism turned to identity politics and became enmeshed with the trend towards biomedicalization, which again engendered new debates over reproductive regulation. The Human Fertilization and Embryo Act (2008), which sought to preserve the autonomy of women alongside the foetus is one example of the regulative aspect of feminist and biomedical involvement in reproductive rights. Alongside this was increasing agitation about the effects of neoliberalism and its promotion of biological parenting as a moral enterprise. Notably, the EU reflected these concerns by raising questions over whether fertility services - when conceived as a choice - should be regulated at all. .88

In the global north, campaigning around many of the issues of reproductive rights did not progress from a unified collective movement, as seen in the Third World. Instead, debates 
on reproductive rights represented and reflected competing feminist perspectives and interest groups. Writers also point to a paradox that while new reproductive technologies expanded and were made accessible, other reproductive rights were coming under attack, such as access to abortion and the contraceptive pill, and welfare rights for children, especially those born to single parents. By virtue of its in-between state, infertility was a site where feminist academics in the First World campaigned with competing interests. The relentless advocacy of feminist goals of autonomy and status paralleled feminist discourses of control over reproduction. Charis $\mathrm{M}$. Thompson argues that the feminist paradox is that "feminists are well placed to understand the special burden involuntary childlessness places on women but are ambivalent about supporting women who seek infertility treatments because it seems to lend implicit support to conventional gender roles and gendered stratification". ${ }^{89}$ Others identify a different feminist paradox: that in the 1980s,

criticism of motherhood as establishing barriers to personal development and freedom, proceeded alongside the endorsement of technologies that circumvent "virtually any obstacle to procreation, including older age", and therefore effectively revision both historical categories of 'barrenness' and the physiological state of menopause. ${ }^{90}$ In brief, by the end of the 1990s, cultural and theoretical debates over infertility had taken centre stage in the global north, and issues such as stratification and injustice had been relegated to the backseat. 91

\section{$\underline{\text { Reproduction and Infertility Discourses in the Global South }}$}

In the Third World feminist perspectives and advocacy around women's reproduction emerged out of two interlocking paradigms, both of whose foundations were rooted in 
capitalism. The first was drawn from a re-visioning of Thomas Malthus' late eighteenth century proposition that unless checked by natural or artificial means, population growth will inevitably outstrip resources and negatively affect economic growth. This view has dominated development agendas in the global south from the 1950s, and continues to do so. ${ }^{92}$ Buoyed by twentieth-century development theory and models that argued the potential benefits of low fertility for the economic growth of the nation ${ }^{93}$, neo-Malthusianism gained ascendancy in development policy, especially at the key international forum, the International Conferences on Population and Development (ICPDs). Through the 1960s to 1980s, this forum set the scene for the dominant ideology underpinning the institution of family planning programmes in the Third World. ${ }^{94}$ A second paradigm informing feminist debates on reproduction was the emerging context of neoliberalism in the 1980s and 1990s as nation after nation abandoned socialist pathways to join those adopting economic liberalization policies, or had such policies mandatorily instituted by the IMF and the World Bank. Neoliberalism was directly responsible for decline in the availability, range, access and quality of services, especially at the primary health care level affecting reproductive health. ${ }^{95}$ Significantly, the deregulation of developing economies also heightened the presence of pharmaceutical corporates and the growth of contraceptive and reproductive technologies in developing nations. The rest of this section elucidates how these paradigms contributed to a new Third World discourse on fertility, which in turn informed discourses on infertility.

Feminist academics in the Third World recognized the empirical evidence that seemed to link low fertility to women's autonomy, status and gender relations, and to development more generally. ${ }^{96}$ While this might seem to suggest a parallel between official neoMalthusian discourses and Third World feminist discourses of control over reproduction, 
nothing could be further from the truth. In the 1980s, Third World feminist writings challenged prominent narratives of the beneficial effects of development, instead pointing out the risk that gendered production and reproduction in the global south would be appropriated for development ends. ${ }^{97}$ From a Third World feminist perspective, therefore, population programmes needed to centre on women's autonomy, lest anti-natalism become an instrument of capitalist accumulation. Alongside the recognition of coercive practices by developing states to enforce population control, such as China's one-child policy, India's forced mass-vasectomies in the 1970s and quinacrine sterilization in the 1980s, and Indonesia's Norplant implantation programmes feminists challenged population programmes from a human rights perspective. Population programmes became a site of resistance for Third World feminists, who simultaneously advocated for access to safe contraceptive and abortion services. ${ }^{98}$ Monica Das Gupta, John Bongaarts and John Cleland summarize the normative feminist perspective of the day:

Micro-studies...find that lower fertility is also associated with better child health and schooling, reduced maternal mortality and morbidity, increased women's labour force participation, and higher household earnings. This is quite aside from the intrinsic human right of being able to control one's own fertility. ${ }^{99}$

The campaign for the "right to control fertility" slowly gathered momentum through the 1970s and 1980s, galvanized by United Nations sponsorship. ${ }^{100}$ The UN Conferences for Women in 1975 (Nairobi), 1985 (Mexico) and 1995 (Beijing), the Declaration of the Decade for Women (1975-1985), and the rapidly burgeoning field of women-in-development fostered transnational networks and shared frameworks. ${ }^{101}$ In the lead-up to the 1994 ICPD in Cairo, these coalesced into a loose but formidable coalition of transnational 
feminist groups campaigning on a platform of reproductive and sexual health and rights. ${ }^{102}$ Relentless and strategic advocacy by the movement through the 1990s succeeded in integrating vocabulary that until then had remained within the feminist movement, such as “informed choices", "inviolable”, "reproductive autonomy", "gender sensitivity”, and "quality of care", into the ICPD Programme of Action (POA). This vocabulary entered the discourse of strategic mainstream population policy for the 179 countries that were signatories to the ICPD. ${ }^{103}$ The ICPD POA "marked the beginning of a new era of commitment and willingness on the part of governments", and "urge[d] the empowerment of women both as a highly important end in itself and as a key to improving the quality of life for everyone". 104 The Conference attested that the success of the ICPD goals relied on the provision and maintenance of services - not only those related to family planning, but a broad range of universal primary health care, education, and counselling services for women, men and children, including abortion. This Third World feminist perspective was reinforced at the Beijing Conference for Women in 1995. The UN Platform for Action at Beijing noted that "the human rights of women include their right to have control over and decide freely and responsibly on matters related to their sexuality, including sexual and reproductive health, free of coercion, discrimination and violence". ${ }^{105}$

There was, however, unresolved tension between feminists in the global north and south around the priorities for advocacy. While feminists from Europe and North America stressed abortion rights as fundamental to reproductive rights, this was not a priority for Third World feminists; their main concern was the fight against state-driven antinatalism. ${ }^{106}$ Groups like FINRRAGE (Feminist International Network of Resistance to Reproductive and Genetic Engineering), located women's reproduction within wider global capitalist patriarchal structures, and regarded population policies as part of the 
'technopatriarchal' attempt to dissuade Third World women from "breeding more poor children". Simultaneously they encouraged women in the global north "to breed because they add to consumption demand, which drives capital accumulation". ${ }^{107}$ Within their ideological frame, new reproductive technologies such as IVF were part of the global system that continued to objectify women's reproduction. FINRRAGE's perspective is captured in the words of one of its members, Ute Winkler, who claimed that, "We cannot wait until we have convinced all women who are infertile that they should reject IVF ... IVF is not a solution to infertility. Women are still infertile when they conceive through IVF". ${ }^{108}$

Overall, the primary focus of the reproductive health movement in the global south was on reproductive rights and population control. Significantly, infertility was marginal in these feminist discourses. Aside from an occasional consideration that access to contraception may not be the most important campaigning goal for all women as some "women may not want to control their fertility at all; they may be confronted with infertility"109, or mention of the consequences to marriages as a result of infertility, there was no specific socio-political analysis of infertility or extended attention to care. ${ }^{110}$ Infertility was not mentioned in the POA at Cairo and only one reference was made to it, within the context of a discussion on reproductive disease, in the Beijing Platform for Action: "[c]ancers of the breast and cervix and other cancers of the reproductive system, as well as infertility, affect growing numbers of women and may be preventable, or curable, if detected early". ${ }^{111}$ In other places - as for example in the Indian Government's policy documents on the Reproductive and Child Health (1996) programme - infertility is linked to untreated HIV and AIDS, or even to the reproductive concerns of older people. Within Third World feminist discourse, then, infertility takes a marginal position within debates on reproductive rights, reflecting in part what Rosalind Petchesky cautioned was a "fault line" between the right to choose and the 
drive towards population control that Third World feminists had not quite resolved. ${ }^{112}$ Consequently, in the 1980s and 1990s, this discourse constituted infertility as involuntary and caused by medical or social circumstances, such as continued childbirth, lack of ability to negotiate sexual contact, and exposure to sexual diseases. It also constructed infertility as a preventable problem of women that could be remedied by primary reproductive health care and attention. Addressing the causes of infertility was seen to fall within the realm of primary health care services, as part of the wider population-based free health-care structure. Little was mentioned about the actual treatment of infertility in the context of the developing world. ${ }^{113}$

The Third World feminist response to neoliberalism has been less organized, unequivocal and consistent. Indeed, the impact of the liberalization of markets for reproductive health has created, or deepened, schisms amongst feminist advocates, governments, markets and individual women as regards their understandings of reproductive rights. By the early 1990s, contraceptives were readily available on the open market, upstaging the state as the primary regulated source of contraception. As commercial enterprises entered the market for contraceptives, a smorgasbord of new and technologically advanced products became more readily available for individual purchase. ${ }^{114}$ Interestingly, the growth in fertility control products paralleled the growth in infertility treatment products and services. In many developing countries, the number of private clinics offering ART and infertility services, including surrogacy, mushroomed. Given the lack of regulation of the sector, its commercialization has facilitated the expansion of global, rather than domestic, 'reproductive tourism', especially within Asia. ${ }^{115}$ In a country like India, for example, there are over 3000 infertility clinics, whose preferred clientele are foreign nationals in an industry estimated roughly to be around $\$ 400$ million USD. ${ }^{116}$ For this reason, in 2010 the 
Indian State enacted draft legislation to regulate the growth of this sector. ${ }^{117}$ Importantly, given the costs of many reproductive technologies, affordability rather than need has become one of the key criteria in determining access to them, and infertility treatment has therefore become stratified as the purview of the affluent.

The transnational reproductive health coalition has largely been silent in response to this emerging trend. A decade after the ICPD, the movement does not appear to have formulated a clear position or sustained analysis of infertility. In 2009 Adrienne Germain, Ruth Dixon-Mueller and Gita Sen, stalwarts of the international reproductive health movement, called for the international community to get "back to the basics" of the ICPD 1994, and highlighted areas which demanded focused attention. Infertility does not appear on their list. ${ }^{118}$ There is similar absence of reference to infertility in the International Women's Health Coalition's comment on the future of the ICPD. ${ }^{119}$ Outside of the movement per se, feminist scholars from the south have been divided on the issue of ART and surrogacy. There are those who see commercialization as encouraging the production of disembodied and fragmented female bodies, thereby compromising women's selfdetermination. ${ }^{120}$ Their view is supported by academics in the global north who consider cross-border trade and its accompanying exploitation to be a failure of "reproductive justice". ${ }^{121}$ How far these views are reflective of the experiences of women in the Third World is a matter of debate, as some first-person accounts from the global south suggest that individual women relish the freedom that reproductive technology affords, despite the risks and costs. ${ }^{122}$

More recent approaches from supra-national organizations recognize infertile women as constituting a special category, and as deserving support with both prevention of fertility 
problems and treatment for existing problems. ${ }^{123}$ This validates an explicit politics of recognition for infertile women as having rights to bear children. This new politics of recognition is due to the growing acceptance and success of ART technology in the global south, and the reframing of infertility as a problem related to issues of social justice, regardless of population pressures. ${ }^{124}$ In comparison to the global north, then the progress towards making infertility a public health issue has been slow.

Incongruent Emancipations: Infertility and its Stratifications

As our analysis has demonstrated, since the 1970s, feminist discourses around infertility have proliferated and so have the contradictions amongst them. Discourses of emancipation that emerged in the global north were either irrelevant to Third World women, or reliant on the appropriation of their bodies and reproductive power; equally the conditions of infertile women in the global south scarcely figured within global discourses of women's reproductive autonomy. As Faye D. Ginsberg and Rayna Rapp argue, from the 1970s the idea of a "politics of reproduction", which demanded examination of the multiple levels on which reproductive practices, policies and politics were enacted, started to dominate feminist discussions. Analyses of the politics of reproduction considered the social, moral, ethical, economic and religious interests at stake in reproductive technologies, from diagnosis to donation, as a set of relationships between multiple actors and agencies: local and global organizations, state and private interests, and different professional groups. Although the differing perspectives revealed by these analyses might be viewed as evidence of ideological fragmentation within feminism, in reality they reflected the multiplicity of feminist perspectives on socio-political institutional frameworks which 
were increasingly underwritten by capitalist interests. In this section, we reflect on the place of emancipation and "stratified reproduction" in feminist conceptualizations of infertility.

Within feminist discourse, the idea of stratified reproduction has been framed in two main ways. At the end of the second wave, it was primarily conceptualised as a means of drawing attention to inequalities in access to reproductive technologies and the importance accorded to infertility between the developed and developing worlds. A body of feminist work from the north and the south highlighted the inequalities in the delivery, accessibility and affordability of infertility treatments to women in these global regions concluding that, there are 'two worlds of infertility' where the effects of infertility were experienced more severely in non-western world. ${ }^{125}$ In addressing stratifications in reproductive rights, the focus turned to the exploitative relationships between the two worlds, not merely the gaps between them. ARTs, in particular, were identified as both reflecting and contributing to a widening of local and global divisions. Conceptually, stratification offered a heuristic lens to reflect on distinctions between the moral, legal and religious handling of ARTs and a range of structural and economic factors that facilitated the procurement by western women of the technology or surrogates available in the non-western world. ${ }^{126}$ In particular, this work described how global policies and practices in health care converged with medicalization processes to potentially increase the patriarchal-capitalist appropriation of medical care, so that infertility has become the "latest and most powerful instance in which male doctors and 'pharmacrats' use biotechnology to usurp female reproductivity". ${ }^{127}$ Finally, this body of work has reiterated the imperial intent of biomedicalized capitalism in transferring the cultural emphasis on the importance of biological parenthood from the developed to the developing world. 
The conceptual framing of infertility and reproductive technologies as 'stratified' was successful within the specific discourse of the First World as being in a state of advanced capitalism, distinct from the Third World and its early-stage capitalism. This dialectic between the First and Third Worlds is what Fraser refers to in her account of the misframing of global justice. ${ }^{128}$ This traditional north-south dialectic is also what we have identified as the Janus face of infertility. Like Fraser, we argue this dialectic has been undermined by the intertwining of consumerism, capitalism and neoliberalism within the global infertility market. We discuss the effects of this 'Janus face' below.

The dominant lens of stratification failed to encompass the breadth of inequities beyond the north-south divide, effectively ignoring those marginalized or advantaged within each context. Contemporary feminist debates established that low-income, minority, and lesbian women within the First and Third Worlds had unequal access to high-tech, expensive ARTs. Furthermore, little attention had been paid to the differently gendered nature of infertility, including the different causes of infertility or the different applications of reproductive technology on men's and women's bodies. Male infertility was hidden due to a combination of factors that included a lack of infertility treatments for men, sensitivities around the collection of sperm, and the conflation of male infertility with impotency and emasculation. ${ }^{129}$ Additionally, ARTs were recognized as being applied to women's bodies in more invasive ways. These differences point to inequalities that emerged within the global north and global south. Economic analyses of reproductive choice in the emergent capitalist and biomedicalized world order of infertility treatment suggest that wealth accumulation and purchasing power was not limited to wealthy, western women in the global north alone but was more widespread as a class issue in both the global north and 
south. For low-income women, at best infertility received attention only when coupled with reproductive health disease.

In the last decade, wider social transformations that have undermined the dialectic of developed-developing world have led to challenges to the dominant narrative of reproductive stratification of the "two worlds". In its place, the global south is revisioned as being rapidly prosperous and technologically advanced, where an insatiable and newly affluent middle-class drives markets, including in medical technologies. As John Comaroff and Jean Comaroff (2009) argue, the south no longer seeks to emulate the north - "old margins are becoming new frontiers" - but they also caution that "it is the South that often is the first to feel the effects of world-historical forces [...] thus to pre-figure the future of the global North". ${ }^{130}$ In this revisioning of the dialectic, reproductive stratification is more complicated than many feminist texts initially conceived.

To contextualize our discussion in light of Fraser's argument, we conclude that as the politics of recognition has converged with a consumer-driven demand for medically advanced access to reproductive technologies, reproductive stratifications within the global south has assumed greater significance than long-standing asymmetries between the First and the Third Worlds. Notions of women's emancipation in the global south have taken root within the rhetoric of individual choices and recognition, and in place of a collective response to state-organized programmes and redistribution of resources. The same discourse of emancipation is found in the global north, where infertility treatment is already framed both as an exercise of individual rights and as a lifestyle choice, and has been colonized by private business actors. Infertility is no longer primarily a basis for claims to better public healthcare provision or political accountability. As the state rescinds the 
responsibilities of a provider, it assumes the role of regulator - often of global biomedical enterprises.

\section{Conclusion: The Janus Fortunes of Infertility Debates}

In this paper we have argued that since the 1970s there have been differences in feminist understandings about infertility in the global north and the global south. We have attempted to highlight in equal measure the contradictory and sometimes disabling conceptualizations of emancipation. Feminists, for example, have been generally critical of the impact of reproductive technologies on women, but some have embraced the view that women are empowered by technologies that promote individual rights and choices in overcoming infertility. While in the early years of the second wave, feminism mainly focused attention on western women's struggles with medicalization, by its end in the 1980s, there was a greater appreciation of the different and unequal experiences of women of different ethnicities, classes, sexualities and ages in the global north. In the 1990s, the debates took on a transnational scope, as scholars sought both to recognize the experiences of infertile women in the Third World and to expose the relationship between the advancement of infertile western women's rights and the losses of their counterparts in the global south. As feminism moved into the era of advanced global capitalism, neoliberal revisionings of emancipation inflected feminist understandings of infertility. In all, feminist perspectives on infertility have spanned liberal equality arguments, radical scholarship eschewing the patriarchal biomedicalization of women's reproduction, both ethnocentric and postcolonial critiques of justice, and political economy analyses. Such 'disorganized' effects, in Nancy Fraser's words are not uncommon, and are rooted in the subtle but insidious entanglements between neoliberalism and feminism. ${ }^{131}$ In light of such history, we note that 
debates once again have shifted in the new millennium, directed now by the global south into claims for similar rights of reproductive autonomy and recognition.

Although the historical narrative followed divergent, if interconnected, pathways in the global north and south, there are similarities in feminist responses to the kinds of ideas of global justice outlined by Fraser. There was, however, a time lag. In the global north, feminisms "sought to question core features of the capitalist modernity that social democracy has naturalised: materialism, consumerism [...] sexual repression". ${ }^{132}$ To this list we add medicalization, which offered a radical critique of gender exclusions. Fraser's perspective on the ways in which capitalism has "conscripted" feminism is useful here for understanding the consequent biomedicalized enterprise of infertility. In brief, in the context of neoliberalism, infertile women became subjects for the promotion of new reproductive technologies, and as a result their relationship to a wider struggle over women's reproductive rights became seriously truncated. This reframing of gender justice was part of the zeitgeist which also ignored political concerns about the nature of the globalized reproductive health market, and potential alliances between those in the global north and the global south.

On the other hand, infertile women in the global south were mis-recognized in the concerted feminist response to population control programmes, steeped as it was in a redistributive paradigm. This gap was filled by capitalist commodities as infertility became caught up in the thriving business of medical technology. Drawing on Fraser, we argue that development theorists erred in relying on the idea of gender recognition as essential to achieving parity for infertile women, rather than actively representing them in policy-making processes. For example, if an issue could be represented as an inequality, then policy and 
process could be formulated to address the injustice. In the global south, fertility was represented well, and reproductive rights were advocated as necessary for redistribution. On the other hand, infertility was neither recognized nor represented, and nor were claims made for redistribution; responses to infertility were often local and rarely took into account the global context, as we saw in the responses to population control. In Fraser's view, this misrepresentation meant that infertile women in the south went unnoticed (voiceless) at a crucial period in the 1990s when state-managed capitalism was transitioning into the unfettered capitalist markets of the new millennium. Academic mis-framing of reproductive technologies and experiences of infertility had important implications for how infertility was shaped and managed in the decade that followed. The Janus face of infertility which we have described is therefore not an analysis of a simple dialectic between north and south, but rather is constitutive of a series of misframings both within and between these 'regions', which reflect the entanglements between feminism and neoliberalism within the global context.

Fraser's argument can also be applied to feminist responses to infertility in recent history, which could also be described as Janus-faced. During the decades from the 1970 s to the 2000s, there was a cultural and economic shift towards a global politics of neoliberalism. This was matched by a shift in feminist thinking, and in other social and political movements, away from a politics of redistribution towards a politics of recognition. This shift intensified the spread of capitalism in fertility medicine, permitting the intervention of new actors outside of the boundaries of state, and the realization of new, previously invisible identities. What is needed therefore, is a new global feminist politics that can navigate a consensual path through incongruent conceptualizations of emancipation, and its relation to infertility. In charting new pathways forward, this global feminist politics will 
have to appreciate, as Fraser argues, "the role of transnational forces in maintaining gender injustice". ${ }^{133}$ This new pathway, at the very least, has to addresses the misframing and misrepresentation of infertility and reproductive technologies via an integrated feminist politics that combines economics with identity, recognition and status.

\section{Acknowledgements}

We would like to acknowledge Naomi Simon-Kumar for her research references for this article. 


\section{REFERENCES}

E. O. Akande (2008) 'Affordable Assisted Reproductive Technologies in Developing Countries: Pros and Cons', Human Reproduction (ESHRE, European Society for Human Reproduction and Embryology), 1, 12-14.

L. Beneria and G. Sen (1981) 'Accumulation, Reproduction, and Women's Role in Economic Development: Boserup Revisited', Signs, 7(2), 279-298.

L. Beneria and G. Sen (1982) 'Class and Gender Inequalities and Women's Role in Economic Development: Theoretical and Practical Implications', Feminist Studies, 8(1), 157-176.

Bentley, G R. and Mascie-Taylor, C. G. N. (2000) 'Introductory Chapter' in G.R. Bentley and C. G. N. Mascie-Taylor (eds.) Infertility in the Modern World: Present and Future Prospects (Cambridge: Cambridge University Press), pp.1-13.

R. Berger and M. S. Paul (2013) 'Plurality of Methodologies to Bridge the Gap Between Research and Practice: A Case Study in Infertility Research'. Forum: Qualitative Social Research, 15(1), Art. 8, http://nbn-resolving.de/urn:nbn:de:0114-fqs140185, date accessed 23 August 2015.

Bertarelli Foundation Scientific Board (2000) Public Perception on Infertility and its

Treatment: An International Survey, Human Reproduction, 15(2), 330-334.

L. Birke (1999). Feminism and the Biological Body. (Edinburgh: Edinburgh University Press).

Buchanan, A. and Rotkirch, A. (2013) 'No Time for Children? The Key Questions' in A. Buchanan and A. Rotkirch (eds.) Fertility Rates and Population Decline? No Time for Children (Basingstoke: Palgrave Macmillan), pp.3-21. 
Caldwell, J.C. and Caldwell, P. (2000) 'From STD epidemics to AIDS: perspective on sunSaharan Africa' in G.R. Bentley and C. G. N. Mascie-Taylor (eds.) Infertility in the Modern World: present and future prospects (Cambridge: Cambridge University Press). p.153-186

Clarke, A. E., Shin, J. K., Mamo, L., Fosket, J. R. and Fishman, J. R. (2010). 'A Theoretical and Substantive Introduction' in A. E Clarke, L. Mamo, J. R. Fosket, J. R. Fischman and J. K. Shim (eds.) Biomedicalization: Technoscience, Heath and IIIness in the U.S (Durham: Duke), pp.1-44.

J. Cohen, A. Trounson, K. Dawson, H. Jones, J. Hazekamp, K. G. Nygren, L. Hamberger (2005) 'The Early Days of IVF Outside the UK', Human Reproduction Update, 11(5), 439-59.

J. L Comaroff and J Comaroff (2009) Infertility, Inc. Chicago: University of Chicago Press.

R. J. Cook (1995) 'Human Rights and Reproductive Self-Determination', The American University Law Review, 44(975), pp.976-1076.

S. Correa (1994). Population and Reproductive Rights: Feminist Perspectives From The South. (London: Zed Books).

Correa, S. and Petchesky, R. (1994) 'Reproductive and Sexual Rights: A Feminist Perspective' in G. Sen, A. Germaine and L. Chen (eds.) Population Policies Reconsidered: Health, Empowerment, And Rights. (Boston, Massachusetts: Harvard University Press), pp. 107-126.

M. Das Gupta, J. Bongaarts and J. Cleland (2011) 'Population, Poverty, and Sustainable Development: A Review of the Evidence'. World Bank Policy Research Working Paper Series, No. 5719, http://ssrn.com/abstract=1876295, date accessed 25 August 2015. 
R. Dixon-Mueller (1993) Population Policy and Women's Rights: Transforming Reproductive Choice, (Westport, Connecticut: Praeger).

Dixon-Mueller, R. and Germain, A. (1994) 'Population Policy and Feminist Political Action in Three Developing Countries' in J. Finkle and C. A. Mclntosh (eds.) The New Politics of Population: Conflict and Consensus in Family Planning (New York: The Population Council), pp.197-219.

S. J. Dyer, N. Abrahams, M. Hoffman and Z. M. van der Spuy (2002) 'Infertility in South Africa: Women's Reproductive Health Knowledge and Treatment-Seeking Behaviour for Involuntary Childlessness', Human Reproduction, 17(6), 1657-1662.

P. R. Ehrlich (1968) The Population Bomb, (New York: Ballantine).

B. Ehrenreich and D. English, D. (1979) For Her Own Good: 150 Years of the Experts' Advice to Women, (London: Pluto Press).

J. L. Finkle and B. B. Crane (1975) 'The Politics of Bucharest: Population, Development, and the New International Economic Order', Population and Development Review, 1(1), 87-114.

J. L. Finkle and B. B. Crane (1985) 'Ideology and Politics at Mexico City: The United States at the 1984 International Conference on Population', Population and Development Review, 11(1), 1-28.

S. Firestone (1970) The Dialectic of Sex: The Case for Feminist Revolution, (New York: Morrow).

Fishel,S. Dowell, K and Thornton S (2000) 'Reproductive possibilities for infertile couples: present and future' in G.R. Bentley and C. G. N. Mascie-Taylor (eds.) Infertility in the Modern World: present and future prospects (Cambridge: Cambridge University Press). p.17-45. 
M. Foucault (1973). The Order of Things: An Archaeology of the Human Sciences (New York: Vintage) (translation of Les mots et les choses, Editions Gallimard, 1966).

S. Franklin (2013) Biological Relatives: IVF, Stem Cells and the Future of Kinship (Durham:

Duke University Press).

N. Fraser (2009) Scales of Justice: Reimagining Political Space in a Globalizing World (New York: Colombia University Press).

N. Fraser (2013) Fortunes of Feminism: From State-Managed Capitalism to Neoliberal Crisis (London: Verso).

Garcia-Moreno, C. and Claro A. (1994) 'Challenges from the Women's Health Movement:

Women's Rights versus Population Control' in G. Sen, A. Germain and L. Chen (eds.) Population Policies Reconsidered: Health, Empowerment and Rights (Boston, Massachusetts: Harvard University Press), pp. 47-62.

A. Germain, R. Dixon-Mueller, \& G. Sen (2009). Back to Basics: HIV/AIDS Belongs with Sexual and Reproductive Health. Bulletin of the World Health Organization, 87(11), 840-845.

D. Gerson (1989) 'Infertility and the Construction of Desperation', Socialist Review 89(3), 45-66.

D. L Herbert, J. C. Lucke and A. J. Dobson (2009) 'Infertility in Australia Circa 1980: An Historical Population Perspective on the Uptake of Fertility Treatment by Australian Women Born in 1946-51', Australian New Zealand Journal of Public Health, 33(6), $507-14$

R. Hubbard (1990) The Politics of Women's Biology, (New Brunswick: Rutgers University Press).

F. Girard (2014) 'Taking ICPD Beyond 2015: Negotiating Sexual and Reproductive Rights in the Next Development Agenda', Global Public Health, 9(6), 607-619. 
F. Ginsberg and R. Rapp (1991) 'The Politics of Reproduction', Annual Review of Anthropology, 20, 311-43.

A. L. Greil, K. Slauson-Blevins and J. McQuillan (2010) 'The Experience of Infertility: A Review of Recent Literature', Sociology of Health and IIIness, 32(1), 140-162.

A. L Greil and J. McQuillan (2010) “Trying” Times: Medicalization, Intent, and Ambiguity in the Definition of Infertility', Medical Anthropology Quarterly, 24(2), 137-156.

S. Grimes (1998) 'From Population Control to 'Reproductive Rights': Ideological Influences in Population Policy', Third World Quarterly, 19(3), 375-394.

J. A. Gupta and A Richters (2008) ‘Embodied Subjects and Fragmented Objects: Women’s Bodies, Assisted Reproduction Technologies and the Right to Self-Determination', Journal of Bioethical Inquiry, 5(4), 239-249.

K. Hardee, K Agarwal, N. Luke, E. Wilson, M. Pendzich, M. Farrell and H. Cross (1999) 'Reproductive Health Policies and Programs in Eight Countries: Progress Since Cairo', International Family Planning Perspectives, 25, S2-S9.

A. P. Hardon (1992) 'The Needs of Women Versus the Interests of Family Planning Personnel, Policy-Makers and Researchers: Conflicting Views on Safety and Acceptability of Contraceptives', Social Science \& Medicine, 35(6), 753-766.

D. L Herbert, J. C. Lucke and A. J. Dobson (2009) 'Infertility in Australia Circa 1980: An Historical Population Perspective on the Uptake of Fertility Treatment by Australian Women Born in 1946-51', Australian New Zealand Journal of Public Health, 33(6), 507-14.

M. Inhorn and D. Birenbaum-Carmeli (2008) 'Assisted Reproductive Technologies and Culture Change', Annual Review of Anthropology, 37, 177-196.

Inhorn, M.C. (2003) Global infertility and the globalization of new reproductive technologies: illustrations from Egypt, Social Science \& Medicine, 56, 1837-1851. 
S.J. Jejeebhoy (1991) 'Women's Status and Fertility: Successive Cross-Sectional Evidence from Tamil Nadu, India, 1970-80', Studies in Family Planning, 22(4), 217-230.

N. Kabeer (1994) Reversed Realities: Gender Hierarchies in Development Thought (London: Verso).

L. Leonard (2010) ‘Problematizing Fertility: "Scientific” Accounts and Chadian Women's Narratives'. in M. C Inhorn and F. van Balen (eds.) Infertility Around the Globe: New Thinking on Childlessness, Gender and Reproductive Technologies (London, UK: University of California Press), pp193-214.

R. Lesthaeghe and G. Moors (2000) 'Recent Trends in Fertility and Household Formation in the Industrialized World', Review of Population and Social Policy, 9, 121-170.

D. Lupton (1994) Medicine as Culture: Illness, Disease and the Body in Western Societies (London: Sage).

T. Mahajan, Deepa. V, S. Chickerur, and Sarojini. N. (2012) Birthing A Market: A Study on Commercial Surrogacy. New Delhi: Sama-Resource Group for Women and Health, http://www.samawomenshealth.org/downloads/Birthing\%20A\%20Market.pdf, accessed $3^{\text {rd }}$ September 2015.

M. N. Mascarenhas, S. R. Flaxman, T. Boerman, S. Vanderpoel and G. A. Stevens (2012) National, Regional, and Global Trends in Infertility Prevalence Since 1990: A Systematic Analysis of 277 Health Surveys, http://journals.plos.org/plosmedicine/article?id=10.1371/journal.pmed.1001356, date accessed 6 August 2015.

L. Mamo. (2007) Queering Reproduction: Achieving Pregnancy in the Age of Technoscience (Durham: Duke University Press)

Mamo, L. (2010) 'Fertility Inc: Consumption and Subjectification in US lesbian Reproductive Practices' in A. E. Clarke, Laura Mamo, J. R. Fosket, J. R. Fischman 
and J. K. Shim (eds.) Biomedicalization: Technoscience, Heath and IIIness in the U.S. (Durham: Duke), pp.173-197.

K. O. Mason (1987) 'The Impact of Women's Social Position on Fertility in Developing Countries', Sociological Forum, 2(4), 718-745.

G. McNicoll (1992) 'Changing Fertility Patterns and Policies in the Third World', Annual Review of Sociology, 18, 85-108.

M. McNeil, I. Varcoe and S. Yearley, S (1990) (eds.). The New Reproductive Technologies (New York: St. Martin's Press).

C. Miall (1986) 'The Stigma of Involuntary Childlessness', Social Problems, 33(4), 268-82

S. Moore (2010) 'Is the Healthy Body Gendered? Toward a Feminist Critique of the New Paradigm of Health', Body and Society, 16, 95-118.

Ministry of Health and Family Welfare (2010) The Assisted Reproductive Technologies (Regulation) Bill - 2010 http://icmr.nic.in/guide/ART\%20REGULATION\%20Draft\%20Bill1.pdf, date accessed $27^{\text {th }}$ August 2015.

M. Mukherjee and S. B. Nadimipally (2006) 'Assisted Reproductive Technologies in India', Development, 49(4), 128-134.

M. Murphy (2012) Seizing the Means of Reproduction: Entanglements of Feminisms, Health and Technoscience. (Durham: Duke University Press).

R. D. Nachtigall (2006) 'International Disparities in Access to Infertility Services', Fertility and Sterility, 85(4), 871-875.

J. Newman and E. Kuhlmann (2007) 'Consumers Enter the Political Stage? The Modernization of Health Care in Britain and Germany', Journal of European Social Policy, 17(2), 99-111.

A. Oakley (1986) The Captured Womb (Oxford: Blackwell). 
W. Ombelet (2011) 'Global Access to Infertility Care In Developing Countries: A Case Of Human Rights, Equity And Social Justice', Facts, Views \& Vision in ObGyn, 3(4), 257266.

G. Parker (2015) 'Making Sense of ART Through the Lens of Reproductive Justice', Women's Studies Journal, 29(1), 41-44.

R. P. Petchesky (1995) 'From Population Control to Reproductive Rights: Feminist Fault Lines', Reproductive Health Matters, 3(6), 152-161.

M. Rao (2004). From Population Control to Reproductive Health: Malthusian Arithmetic, (New Delhi: Sage).

M. Rao and S. Sexton (eds) (2010) Markets and Malthus: Population, Gender and Health in Neo-liberal Times, (New Delhi: Sage).

H. Roberts (ed) (1981) Women, Health and Reproduction (London: Routledge).

Riska, E (2010) 'Gender and Medicalization and Biomedicalization Theories' in A. E. Clarke, Laura Mamo, J. R. Fosket, J. R. Fischman and J. K. Shim (eds.) Biomedicalization: Technoscience, Heath and IIIness in the U.S. (Durham: Duke), pp.147-170.

N. Rose (2006) The Politics of Life Itself: Biomedicine, Power, and Subjectivity in the Twenty-First Century, (New Jersey: Princeton University Press).

S.O. Rutstein and I.H. Shah (2004) Infecundity, Infertility, and Childlessness in Developing Countries. DHS Comparative Reports No 9, Calverton, Maryland, USA: ORC Macro and the World Health Organization www.who.int/reproductivehealth/topics/infertility/DHS-CR9.pdf, date accessed 27 March 2015.

F. T. Sai (1997) 'The ICPD Programme of Action: Pious Hope or a Workable Guide?' Health Transition Review, 7(4), 1-5. 
Sandelowski, M. and de Lacy, S. (2002) 'The Uses of a 'Disease': Infertility as a Rhetorical Vehicle,' in M. C Inhorn and F. van Balen (eds.) Infertility Around the Globe: New Thinking on Childlessness, Gender and Reproductive Technologies (London, UK: University of California Press), pp.33-51.

Sciarra, J (1994) Infertility: An international health problem. International Journal of Gynaecology and Obstetrics. 46 (1994) 155-163,

G. Sen, A. Germain, and L. C. Chen (eds.) (1994) Population Policies Reconsidered: Health, Empowerment, And Rights (Boston, Massachusetts: Harvard University Press).

G. Sen and C. Grown (1987) ‘Development Alternatives with Women for a New Era (DAWN)', Development, Crises and Alternative Visions: Third World Women's Perspectives, (New York: Monthly Press Review)

N. Sheoran (2015). 'Stratified Contraception': Emergency Contraceptive Pills and Women's Differential Experiences in Contemporary India, Medical Anthropology, 34 (3), 243258.

R. Simmons (1996) 'Women's Lives in Transition: A Qualitative Analysis of the Fertility Decline in Bangladesh', Studies in Family Planning, 7(5), 251-268.

R. Simon-Kumar (2006). Marketing' Reproduction?: Ideology and Population Policy in India (New Delhi: Zubaan).

R. Simon-Kumar (2007) 'Neo-liberal Development and Reproductive Health in India: The Making of the Personal and the Political', Indian Journal of Gender Studies, 14(3), 355-385.

Stabile, C. (1994) "Shooting the Mother: Fetal Photograph and the Politics of Disappearance," in C. Stabile (ed.) Feminism and the Technological Fix (Manchester: Manchester University Press), pp.178-205. 
H. Standing (2002) 'An Overview of Changing Agendas in Health Sector Reforms', Reproductive Health Matters, 10(20), 19-28.

Strathern, M. (1999) 'Introduction, First Edition: A Question of Context', in J. Edwards, S. Franklin, E Hirsch, F Price, and M Strathern (eds.) Technologies of Procreation: Kinship in the Age of Assisted Conception, 2nd edn (London: Routledge).

S. Tandulwadkar, P. Lodha, \& V. Kharb (2012). 'Congenital malformations and assisted reproductive technique: Where is assisted reproductive technique taking us?' Journal of Human Reproductive Sciences, 5(3), 244-247.

T. Ahmad (2012)' Bioethics legislation in selected countries', The Law Library of Congress, Global Legal Research Centre LL File No. 2012-008118, https://www.loc.gov/law/help/bioethics 2012-008118FINAL.pdf, accessed 23 ${ }^{\text {rd }}$ Dec. 2015.

Thompson, C. M. (2002) 'Fertile Ground: Feminist Theorize Infertility', in M. C. Inhorn and F. van Balen (eds.) Infertility Around the Globe: New Thinking on Childlessness, Gender and Reproductive Technologies (London, UK: University of California Press), pp.52-78

Tinker, I. (1991) 'The Making of a Field: Advocates, Practitioners and Scholars', in I. Tinker (ed.) Persistent Inequalities: Women and World Development (Oxford: Oxford University Press), pp.27-53.

UNFPA (2004) Programme of Action: Adopted at the International Conference on Population and Development, http://www.unfpa.org/sites/default/files/eventpdf/PoA_en.pdf, date accessed $27^{\text {th }}$ August 2015

United Nations (1995) The Beijing Declaration and the Platform for Action, http://www.un.org/womenwatch/daw/beijing/pdf/BDPfA\%20E.pdf_date accessed $27^{\text {th }}$ August 2015. 
United Nations (2014) Framework of Actions for the Follow-up to the Programme of Action of the International Conference on Population and Development Beyond 2014 Report of the Secretary-General, New York: United Nations.

http://icpdbeyond2014.org/uploads/browser/files/93632_unfpa_eng_web.pdf, date accessed on 11 August 2015.

van Balen, F. and Inhorn M. C. (2002) 'Introduction: Interpreting Infertility: A View from the Social Sciences' in F. van Balen and M. C Inhorn (eds.) Infertility Around the Globe: New Thinking on Childlessness, Gender and Reproductive Technologies (London, UK: University of California Press), pp3-32.

van Balen, F. (2002) 'The Psychologization of Infertility', in M. C Inhorn and F. van Balen (eds.) Infertility Around the Globe: New Thinking on Childlessness, Gender and Reproductive Technologies (London, UK: University of California Press), pp.79-98. Vayena, E. (2009) 'Assisted Reproduction in Developing Countries: the Debate at a Turning Point', in F. Simonstein (ed.) Reprogen-Ethics and the Future of Gender (Netherlands: Springer) pp. 65-77.

J. Wang and M. V. Sauer MV (2006) 'In Vitro Fertilization (IVF): A Review of 3 Decades of Clinical Innovation and Technological Advancement', Therapeutics and Clinical Risk Management, 2(4) 355-364

A. Whittaker and A Speier (2010) "Cycling Overseas": Care, Commodification, and Stratification in Cross-Border Reproductive Travel', Medical Anthropology, 29 (4), 363-383.

A. Whittaker (2011) 'Cross-border Assisted Reproduction Care in Asia: Implications for Access, Equity and Regulations', Reproductive Health Matters, 19(37), 107-116. World Health Organization (2001) WHO (2001) Reproductive health indicators for global monitoring. Report of the Second Interagency Meeting, Geneva, 17-19 July, 2000. 
Geneva, World Health Organization, 2001 (document WHO/RHR/01.19), date accessed 2 December 2015.

World Health Organization (1995) Technical Report Series No. 820. Recent Advances in Medically Assisted Conception. http://apps. who.int/iris/handle/10665/38679?locale=fr date accessed 27 August 2015

World Health Organization. (1991). Infertility: A tabulation of available data on prevalence of primary and secondary infertility. Geneva: Programme on maternal health and family planning, Division of Family Health.

http://apps.who.int/iris/bitstream/10665/59769/1/WHO_MCH_91.9.pdf accessed 9 December 2015

World Health Organization (1975) 'Technical Report Series No. 582 The Epidemiology of Infertility: Report of a WHO Scientific Group. [Meeting held in Geneva from 30 June to 4 July 1975]' Geneva: World Health Organization http://apps.who.int/iris/bitstream/10665/37422/1/WHO_TRS_582_eng.pdf, date accessed 27 August 2015.

Zegers-Hochschild, F., Adamson, G.D., de Mouzon, J., Ishihara, O.,Mansour, R., Nygren., K., Sullivan, E., and Vanderpoel, S. (2009), International Committee for Monitoring Assisted Reproductive Technology (ICMART) and the World Health Organization (WHO) revised glossary of ART terminology, Fertility and Sterility, 92(5), 1520-1525. 
1 This paper uses terms such as global south, global north, First/ Third World, developed/ developing interchangeably, but with caution. These terms are used in part to reflect the thinking of the time when the scholarship under discussion was produced. In general, global south/ First World/ developed refer to countries in North America and Europe, while the global north/ Third World/ developing world consists of Asia, Africa, and Latin America. These divisions are derived from mid-twentieth century categorizations based on levels of wealth and poverty. Arguably, in the twenty-first century, the distribution of wealth is not restricted to these boundaries. Asia, particularly, has seen significant wealth increases without a commensurate decline in poverty.

2 In the global north, this was reflected in the rise of the second wave of feminism, while in the global south, there was a concomitant emergence of women-in-development and Third World-led transnational feminism. ${ }^{3}$ Thompson, C. M. (2002) 'Fertile Ground: Feminist Theorize Infertility', in M. C. Inhorn and F. van Balen (eds.) Infertility Around the Globe: New Thinking on Childlessness, Gender and Reproductive Technologies (London, UK: University of California Press), p. 53.

${ }^{4}$ N. Fraser (2009) Scales of Justice: Reimagining Political Space in a Globalizing World (New York: Colombia University Press).

${ }^{5}$ Fraser, (2009), p. 221.

${ }^{6}$ N. Fraser (2013) Fortunes of Feminism: From State-Managed Capitalism to Neoliberal Crisis (London: Verso).

${ }^{7}$ S.O. Rutstein and I.H. Shah (2004) Infecundity, Infertility, and Childlessness in Developing Countries. DHS Comparative Reports No 9, Calverton, Maryland, USA: ORC Macro and the World Health Organization www.who.int/reproductivehealth/topics/infertility/DHS-CR9.pdf, date accessed 27 March 2015

${ }^{8}$ World Health Organization (1975) 'Technical Report Series No. 582 The Epidemiology of Infertility: Report of a WHO Scientific Group. [Meeting held in Geneva from 30 June to 4 July 1975]' Geneva: World Health Organization http://apps.who.int/iris/bitstream/10665/37422/1/WHO_TRS_582_eng.pdf, date accessed 27 August 2015, p.6

${ }^{9}$ World Health Organization (1975), p.6

10 Zegers-Hochschild, F., Adamson, G.D., de Mouzon, J., Ishihara, O.,Mansour, R., Nygren., K., Sullivan, E., and Vanderpoel, S. (2009), International Committee for Monitoring Assisted Reproductive Technology (ICMART) and the World Health Organization (WHO) revised glossary of ART terminology, Fertility and Sterility, 92(5), 1520-1525. http://www.icmartivf.org/Glossary_2009_FertilSteril.pdf, accessed 30 November 2015 ${ }^{11}$ World Health Organization (2001) WHO (2001) Reproductive health indicators for global monitoring. Report of the Second Interagency Meeting, Geneva, 17-19 July, 2000. Geneva, World Health Organization, 2001 (document WHO/RHR/01.19), date accessed 2 December 2015.

${ }^{12}$ Sandelowski, M. and de Lacy, S. (2002) 'The Uses of a 'Disease': Infertility as a Rhetorical Vehicle,' in M. C. Inhorn \& F. van Balen (eds.) Infertility Around the Globe: New Thinking on Childlessness, Gender and Reproductive Technologies (London, UK: University of California Press), pp.34-36 .

${ }^{13}$ Zegers-Hochschild, $\mathrm{F}$ et al (2009), p.1522

${ }^{14}$ WHO (1975), p.4

${ }^{15}$ G. McNicoll (1992) 'Changing Fertility Patterns and Policies in the Third World', Annual Review of Sociology, 18, 85-108. (p.85)

${ }^{16}$ G. McNicoll (1992) 'Changing Fertility Patterns and Policies in the Third World', Annual Review of Sociology, 18, 85-108. (p.85-86; 91-92)

${ }^{17}$ R. Lesthaeghe and G. Moors (2000) 'Recent Trends in Fertility and Household Formation in the Industrialized World', Review of Population and Social Policy, 9, 121-170 (p.121)

18 Buchanan, A. and Rotkirch, A. (2013) 'No Time for Children? The Key Questions' in A. Buchanan and A. Rotkirch (eds.) Fertility Rates and Population Decline? No Time for Children (Basingstoke: Palgrave Macmillan), pp.3-21.p.5-7

${ }^{19}$ Mascarenhas MN, Flaxman SR, Boerma T, Vanderpoel S, Stevens GA (2012) National, Regional, and Global Trends in Infertility Prevalence Since 1990: A Systematic Analysis of 277 Health Surveys. PLoS Med 9(12), 1-12 e1001356. doi:10.1371/journal.pmed.1001356 [p.9-10]

${ }^{20}$ Mascarenhas et al, 2012, p.9

${ }^{21}$ D. L Herbert, J. C. Lucke and A. J. Dobson (2009) 'Infertility in Australia Circa 1980: An Historical Population Perspective on the Uptake of Fertility Treatment by Australian Women Born in 1946-51', Australian New Zealand Journal of Public Health, 33(6), 507-14. (p.507)

${ }^{22}$ Inhorn, M.C. (2003) Global infertility and the globalization of new reproductive technologies: illustrations from Egypt, Social Science \& Medicine 56, 1837-1851. (p.1837) 
${ }^{23}$ World Health Organization. (1991). Infertility: A tabulation of available data on prevalence of primary and secondary infertility. Geneva: Programme on maternal health and family planning, Division of Family Health. http://apps.who.int/iris/bitstream/10665/59769/1/WHO MCH 91.9.pdf accessed 9 December 2015 p.2

${ }^{24}$ Fishel,S. Dowell, K and Thornton S (2000) 'Reproductive possibilities for infertile couples: present and future' in G.R. Bentley and C. G. N. Mascie-Taylor (eds.) Infertility in the Modern World: present and future prospects (Cambridge: Cambridge University Press). p.17-45 (p.18)

${ }_{25}$ Healy, D.L.A.O Trounson, A.O. and Andersen, A.N. (1994) Female infertility: causes and treatment, The Lancet, 343(8912), 1539-1544

${ }^{26}$ Sciarra, J (1994) Infertility: An international health problem. International Journal of Gynaecology and Obstetrics. 46 (1994) 155-163, (p.156)

${ }^{27}$ Inhorn, M.C (2003) Global infertility and the globalization of new reproductive technologies: illustrations from Egypt, Social Science \& Medicine 56, 1837-1851. (p.1837; 1839)

${ }^{28}$ Rutstein, S.O. and Shah I.H. 2004, p.24

${ }^{29}$ Mascarenhas et al, 2012, p.1

${ }^{30}$ Caldwell, J.C. and Caldwell, P. (2000) 'From STD epidemics to AIDS: perspective on sun-Saharan Africa' in G.R. Bentley and C. G. N. Mascie-Taylor (eds.) Infertility in the Modern World: present and future prospects (Cambridge: Cambridge University Press). p.153-186 (p.155)

${ }^{31}$ World Health Organization. (1987) Infections, pregnancies, and infertility: Perspectives on prevention. Fertility Sterillity 47: 964,

${ }^{32}$ Rutstein, S.O. and Shah I.H. 2004, 2004, p.24

${ }^{33}$ Sciarra, J (1994) Infertility: An international health problem. International Journal of Gynaecology and Obstetrics. 46 (1994) 155-163, (p.156)

${ }^{34}$ Cates W, Farley TMM, Rowe PJ (1985) 'Worldwide patterns of infertility: Is Africa different?', Lancet,14 (2), 596-598,

35 WHO, 1975

${ }^{36}$ McNicoll, 1992, p.90

${ }^{37}$ Leonard, (2010), p.194

${ }^{38}$ Bertarelli Foundation Scientific Board, 1999

${ }^{39}$ Rutstein, S.O. and Shah I.H, 2004

40 Bertarelli Foundation Scientific Board (2000) Public perception on infertility and its treatment: an

international survey, Human Reproduction, 15(2), 330-334. (p.334)

http://humrep.oxfordjournals.org.abc.cardiff.ac.uk/content/15/2/330.full

${ }^{41}$ Rutstein, S.O. and Shah I.H. 2004,p.3-5

${ }^{42}$ Mascarenhas et al, 2012, p.9

${ }^{43}$ Greil et al, 2010, p.7

${ }^{44}$ van Balen \& Inhorn, 2002, p.12

${ }^{45}$ van Balen \& Inhorn, 2002, pp11

${ }^{46}$ van Balen \& Inhorn, 2002, p.13

${ }^{47}$ Wang and Sauer, 2006, p.355-360

${ }^{48}$ Cohen et al, 2005 J. Cohen, A. Trounson, K. Dawson, H. Jones, J. Hazekamp, K. G. Nygren, L. Hamberger (2005) 'The Early Days of IVF Outside the UK', Human Reproduction Update, 11(5), 439-59 (p.443)

${ }^{49}$ van Balen \& Inhorn, 2002, pp13-18

${ }^{50}$ Ginsberg \& Rapp (1991) 'The Politics of Reproduction' Annual Review of Anthropology, 20, 311-43 (p.329)

${ }^{51}$ Thompson, 2002, p.56

52 Thompson, 2002, p.58

${ }_{53}$ Thompson, 2002, p.57

${ }^{54}$ Ginsberg \& Rapp, 1991, p.312; Firestone, 1970.

${ }_{55}$ Murphy, 2012, p.1-6

${ }^{56}$ Murphy, 2012, p.5

${ }^{57}$ Lupton, 1994, p.155-160

${ }^{58}$ Mamo, 2007, p.130-132

${ }^{59}$ Lupton, 1994

60 Inhorn, 2003, p.1843

61 Inhorn \& Birenbaum-Carmeli, 2008, p.182

62 see Tandulwadkar, Lodha, \& Kharb (2012) for a discussion

63 see Oakley, 1986, p.281-283; van Balen \& Inhorn, 2002, p.13-17; Inhorn \& Birenbaum-Carmeli, 2008, p.183-186; Franklin, 2013, p.155

64 Oakley, 1986; Roberts, 1981; Ehrenreich and English, 1979 
65 Foucault, Michel. 1973. The Order of Things: An Archaeology of the Human Sciences. New York: Vintage (translation of Les mots et les choses, Editions Gallimard, 1966).

66 Birke, 1999, p.56-59

67 Lupton, 1994, p155-160

68 Greil \& McQuillan, 2010, pp137-156

${ }^{69}$ Riska, 2010, pp.155-156

70 Mamo, 2010

${ }^{71}$ Clarke et al, 2003, p.1.

72 Mamo, 2010.

${ }^{73}$ Clarke, 2010

${ }^{74}$ Mamo, 2010

75 Newman and E. Kuhlmann (2007), p. 104.

${ }^{76}$ Mamo, 2007, pp195-199

${ }^{77}$ Arditti et al in Lupton, 1994, p.156-157

78 Lupton, 1994, p.160

79 Stabile, 1994, pp.179-200

80 Stabile, 1994, p.200

81 Rose, 2006, p.15-22

82 Thompson, 2002, p.61-62

83 Lupton, 1994, p. 156.

84 Treichler, 1990, cited in Lupton, 1994, p.156

85 Strathern, 1999, p.166-168

86 Oakley, 1986, p.282

87 Cohen et al, 2005, p.439

88 van Balen and Inhorn, 2002, p.12

89 Thompson, 2002, p. 52.

90 Sandelowski and de Lacey, 2002, p.34; van Balen and Inhorn, 2002.

91 Thompson, 2002, p.65-68

${ }_{92}$ Rao, 2004, p. 19-74; Rao and Sexton, 2010, p. 1-30; Sen et al, 1994, p. 27-46; 47-62;:;Simon-Kumar, 2006, p. 98-128.

${ }^{93}$ Erhlich, 1968

${ }^{94}$ Finkle and Crane, 1975 , p. 89-91, 1985, p. 3-5.

95 Standing, 2002, p. 20-25.

96 Jejeebhoy, 1991, p. 217-230; Mason, 1987, p. 718-741; Sattar (1979) cited in Kabeer, 1994, p.198;

Simmons, 1996, 251-268.

97 Sen and Grown/DAWN, 1987; Beneria and Sen 1981, p. 284-297, 1982, p. 165-172

98 Sen et al 1994, p. 47-62 ; 63-74; Dixon-Mueller, 1993, 29-54; Cook, 1995, p. 984-1004.

99 Das Gupta, Bongaarts and Cleland, 2011, p.15

100 Correa, 1994, p. 56-65; Dixon-Mueller and Germain, 1994, ; Garcia-Moreno and Claro, 1994

101 Tinker, 1991

102 Correa and Petchesky, 1994; Dixon-Mueller and Germain, 1994

103 Grimes, 1998; Sai, 1997; Simon-Kumar, 2006, P. 1-4.

104 UNFPA, 2004; IPCD POA 2004: Foreword, p.iii;

105 United Nations, Platform for Action, Beijing Conference for Women,1995: para 96

106 Correa, 1994, P. 10-66.

107 Kabeer, 1994, p.199

108 Kabeer, 1994, p.201

109 Hardon, 1992, p.758

110 Rutstein, S.O. and Shah I.H. 2004, 2004; Hardee et al, 1999.

111 United Nations, Platform for Action, Beijing Conference for Women, 1995, para 100

112 Petchesky (1995), p. 152.

113 Nachtigall, 2006, p. 873-874.

114 Simon-Kumar, 2007, p. 382.

115 Whittaker, 2010, 2011 
${ }^{116}$ Mahajan et al, 2012, p. 7; see also Ahmad, 2012, p. 42-47. At the time of writing this book, the legislation in India had tightened, curtailing foreign nationals to utilise surrogacy services in India (see Sushmi Dey 'Foreigners may be barred from commissioning surrogacy in India', Times of India, Oct. 16, 2015, http://timesofindia.indiatimes.com/india/Foreigners-may-be-barred-from-commissioning-surrogacy-inIndia/articleshow/49418285.cms?utm_source=twitter.com\&utm_medium=referral\&utm_campaign=TOIIndiaN ews)

117 Ministry of Health and Family Welfare, 2010. See also the guidelines published by the Indian Council of Medical Research (2005) found at http://icmr.nic.in/art/Prilim_Pages.pdf. At the time of writing this book, the government is in the process of consulting further legislation to regulate surrogacy services in India, banning foreigners, same-sex and unmarried individuals or couples from availing of its services. See 'Foreigners may be barred from commissioning surrogacy in India', Times of India, Oct. 16, 2015, http://timesofindia.indiatimes.com/india/Foreigners-may-be-barred-from-commissioning-surrogacyinIndia/articleshow/49418285.cms?utm_source=twitter.com\&utm_medium=referral\&utm_campaign=TOIIndiaN ews)

118 A. Germain, R. Dixon-Mueller, \& G. Sen (2009). Back to Basics: HIV/AIDS Belongs with Sexual and Reproductive Health. Bulletin of the World Health Organization, 87(11), 840-845.

119 Girard, 2014

120 For example, Gupta and Richters, 2008; Mukherjee and Nadimipally, 2006

121 Parker, 2015, p. 41.

122 Sheoran, 2015. Sheoran's paper which focuses on contraceptive technology, rather than infertility technology, nonetheless reflects the changing mood of a new generation of women who see technology as a means to reproductive autonomy.

123 United Nations, 2014, p. 106, 114 and 235.

124 Akande, 2008, P. 12; Ombelet, 2011, p. 257-260, ; Vayena 2009, P. $72-73$

125 Greil et al., 2010, p. 146.

126 (Parker, 2015)

127 Ginsberg \& Rapp, 1991, p.331

128 Fraser, 2013, p.200-208

129 Inhorn and Birenbaum-Carmeli, 2008

130 Comaroff and Comaroff 2012 cited in Sheoran, 2015, p.253; Comaroff and Comaroff 2009.

${ }^{131}$ Fraser, 2013, p.217-226

132 Fraser, 2013, p.3

133 Fraser, 2013, p.113 